\title{
Koncepcja modelu „rachunek kosztów działań w uczelni wyższej"
}

\section{Wstęp}

Czy można wyobrazić sobie funkcjonowanie współczesnych organizacji bez szczegółowej analizy kosztów, które one generują? Z pewnością odpowiedź na to pytanie jest negatywna. Przedsiębiorstwa, aby osiagnąć przychód, najpierw muszą ponieść koszty. Dodatkowo, aby nie stracić, muszą przeanalizować koszty powstające w ramach ich działalności w celu ustalenia odpowiedniej odpłatności za produkty lub usługi. Ale czy taka dbałość o szczegółowe rozliczenie kosztów dotyczy tylko przedsiębiorstw komercyjnych? Otóż nie tylko, w ostatnich latach coraz większy nacisk kładziony jest na dogłębną kalkulacjękosztów w jednostkach sektora finansów publicznych. Związane jest to z wprowadzeniem w 2010 roku $\mathrm{w}$ ustawie o finansach publicznych obowiązku prowadzenia $\mathrm{w}$ tych jednostkach kontroli zarządczej, mającej na celu monitorowanie podstawowych procesów związanych z wydatkowaniem finansów publicznych.

Celem artykułu jest zaprezentowanie istoty rachunku kosztów działań i problemów z jego wdrożeniem na przykładzie hipotetycznej uczelni wyższej.

\section{Istota rachunku działań w sektorze publicznym}

Ustawa o finansach publicznych narzuciła kierownikom jednostek obowiązek prowadzenia kontroli zarządczej zdefiniowanej jako „ogół działań podejmowanych dla zapewnienia realizacji celów i zadań w sposób zgodny z prawem, efektywny, oszczędny i terminowy" [Dz.U. z 2009 r. nr 157, poz. 1240]. Celem wprowadzenia tej kontroli jest zapewnienie w szczególności [Dz.U. z 2009 r. nr 157, poz. 1240]:

- zgodności działalności z przepisami prawa oraz procedurami wewnętrznymi, 
- skuteczności i efektywności działania,

- wiarygodności sprawozdań,

- ochrony zasobów,

- przestrzegania i promowania zasad etycznego postępowania,

- efektywności i skuteczności przepływu informacji,

- zarządzania ryzykiem.

W związku z pojawieniem się kontroli zarządczej w sektorze finansów publicznych, zastosowanie elementów rachunkowości zarządczej staje się rzeczą konieczną. Szczególnie wykorzystanie rachunku kosztów działań umożliwia realizację niektórych z wyżej wymienionych celów. W szczególności zapewnia uzyskanie wiarygodnych informacji na temat kosztów realizowanych działań oraz efektywny i skuteczny przepływ tych informacji. Informacje, jakie można wygenerować stosując rachunek kosztów, dotyczą dwóch głównych grup - związane są one z [Skrypt Kancelarii Prezesa Rady Ministrów, s. 9]:

- kosztochłonnością utrzymania posiadanych zasobów:

- koszt utrzymania jednego urzędnika,

- koszt utrzymania jednego komputera czy $\mathrm{m}^{2}$ obiektu,

- koszt realizacji zadań, np. szkolenie na jednego pracownika,

- kosztochłonnością i efektywnością prowadzonej działalności:

- nakłady poniesione na promocję regionu, uczelni itd.,

- nakłady poniesione na zwiększenie bezpieczeństwa,

- $\quad$ koszty realizacji jednostkowych czynności, np. obsługa typowej sprawy w urzędzie.

Wygenerowanie i upublicznianie tych danych ma na celu unaocznienie skuteczności wydatkowania środków publicznych, których głównym źródłem są podatki, i jest elementem polityki odpowiedzialności społecznej.

J. Glynn, J. Perrin i M. Murphy podkreślają, iż „według zwolenników metody ABC jedną z sytuacji, w której metoda ta sprawdza się bardzo dobrze, jest korzystanie przez firmę ze wspólnych urządzeń produkcyjnych do wytwarzania takich samych lub podobnych produktów (...). Inna sytuacja, w której informacje uzyskane dzięki metodzie ABC mogą się okazać wartościowe, pojawia się wtedy, kiedy firma produkuje różne ilości różnorodnych produktów" [Glynn, Perrin i Murphy 2003, s. 284].

Przykładem podobnego podejścia $\mathrm{w}$ jednostkach sektora finansów publicznych są uczelnie wyższe. Biorąc pod uwagę pierwszą sytuację, w uczelni wyższej jeden wykładowca może być powiązany z prowadzeniem zajęć na kilku wydziałach danej uczelni bądź też na kilku kierunkach. Rozliczenie udziału tego wykładowcy na koszt szkolenia jednego studenta konkretnego kierunku jest więc czynnością niezwykle skomplikowaną a jej opracowanie jest możliwe dzięki specyfice metody ABC. Sytuację drugą natomiast można utożsamiać z liczbą kierunków na 
danym wydziale oraz oszacowaniem kosztu kształcenia jednego studenta na danym kierunku. Sytuację tę komplikują chociażby koszty związane z pracą dziekanatu, który powiązany jest $\mathrm{z}$ każdym $\mathrm{z}$ kierunków, a zatem $\mathrm{z}$ każdym studentem.

Problem rozliczania kosztów na uczelni wyższej pojawia się coraz częściej w ostatnich latach. Związane jest to z coraz większą liczbą studentów, wysokimi oczekiwaniami społeczeństwa, ale przede wszystkim ze zmianą ustawy o szkolnictwie wyższym z 21 kwietnia 2011 roku, która zobowiązuje uczelnie do wdrożenia zasadniczych zmian w ewidencji przychodów i kosztów. Uczelnie mogą prowadzić studia $\mathrm{w}$ trybie stacjonarnym oraz niestacjonarnym. Kształcenie na studiach stacjonarnych finansowane jest $\mathrm{z}$ dotacji otrzymywanych z budżetu państwa, a na studiach niestacjonarnych Prawo o szkolnictwie wyższym wprowadza obowiązek samofinansowania, którego głównym źródłem dochodów są wpływy z tytułu odpłatności za usługi edukacyjne [Miłosz 2012]. Odpłatności te, zgodnie z art. 92 ustawy Prawo o szkolnictwie wyższym, powinny być gromadzone na własnych odrębnych rachunkach bankowych [Dz.U. z 2005 r. nr 164, poz. 1365, z późn. zm.]. Pojawia się jednak problem związany z wysokością opłat za studia. Uczelnie państwowe, jak każda jednostka sektora finansów publicznych, jest instytucją non-profit, a zatem jej działalność nie może przynosić zysków. Wysokość opłaty za studia niestacjonarne znajduje odwołanie w ustawie Prawo o szkolnictwie wyższym, jednak nie precyzuje metody jej obliczania. Według tej ustawy, opłaty ,nie mogą przekraczać kosztów ponoszonych w zakresie niezbędnym do uruchomienia i prowadzenia w danej uczelni odpowiednio studiów lub studiów doktoranckich [Dz.U. z 2005 r. nr 164, poz. 1365, z późn. zm.].

„Ustawa ta jest zatem podstawą do obowiązkowej kalkulacji dokładnego kosztu kształcenia jednego studenta danego kierunku przez wszystkie uczelnie publiczne. Rachunkowość większości uczelni wyższych nie jest jednak tak zaawansowana, aby ocenić poziom tego kosztu. W efekcie opłaty za studia są często zawyżane, co jest niedopuszczalne i niezgodne ze wspomnianym paragrafem ustawy Prawo o szkolnictwie wyższym [Klaus, Ryńca i Kowalski 2007, s. 64].

Jak zauważa H. Miłosz, kontrola Najwyższej Izby Kontroli z 2011 roku wykazała, iż na 27 uczelni publicznych aż 74\% nie prowadzi odrębnej ewidencji księgowej kosztów z podziałem na koszty studiów stacjonarnych i koszty studiów niestacjonarnych. W efekcie można domniemywać, że rektorzy tych uczelni nie są świadomi rozkładu środków z dotacji budżetowych na pokrycie kosztów generowanych przez studia stacjonarne [Miłosz 2012].

Można zatem stwierdzić, iż rachunek kosztów działań jest jedyną metoda, która może poradzić sobie z rozliczeniem kosztów w uczelniach wyższych i dać odpowiedź na podstawowe pytanie dotyczące kosztu kształcenia jednego studenta na konkretnym kierunku. Obecne systemy finansowo-księgowe nie tylko 
nie potrafią skonkretyzować tej kwoty, ale dodatkowo nie przynoszą żadnych istotnych informacji, które mogłyby wspierać proces prognozowania czy też planowania skutków prowadzonych działań. Zastosowanie metody ,,rachunek kosztów działań" może stanowić źródło wiarygodnych informacji kosztowych, na podstawie których rektorzy będą mogli podejmować racjonalne i zgodne z obowiązującymi ich przepisami decyzje.

Aby móc sprawnie, a przede wszystkim efektywnie zarządzać danymi jednostkami, organy podejmujące decyzje o rozdzielaniu środków z budżetu potrzebują niezbędnych do tego informacji możliwych do uzyskania z przeprowadzonego rachunku kosztów działań. Zaliczają się do nich właśnie te dane, które zostały wyróżnione w strukturze rachunku kosztów działań w ujęciu [Zieliński 2007, s. 38]:

- poszczególnych zasobów organizacyjnych, którymi dysponują,

- poszczególnych działań i całych procesów, za realizację których odpowiadają,

- poszczególnych obiektów kosztowych, na rzecz których realizowane są działania i procesy.

Rachunek kosztów działań, tak jak widać to na rysunku 1, umożliwia przepływ kosztów zasobów przez działania do obiektów kosztowych z wykorzystaniem nośników kosztów zasobów oraz nośników kosztów działań. Dzięki przyczynowo-skutkowemu przypisywaniu kosztów wykonanych działań do poszczególnych interesariuszy (obywateli, gmin i powiatów oraz przedsiębiorstw) system $\mathrm{ABC}$ eliminuje $\mathrm{w}$ jednostkach sektora finansów publicznych uśrednianie i arbitralność w alokowaniu kosztów, jakie ma miejsce w tradycyjnych systemach finansowo-księgowych [Skrypt Kancelarii Prezesa Rady Ministrów, s. 28].

Jak zauważa T. Zieliński, kluczowym czynnikiem sukcesu we wdrażaniu systemu rachunku kosztów działań jest przyjęcie procesowej mentalności postrzegania jednostki i zrozumienie pojęcia „działanie”. Funkcjonowanie tej jednostki nie powinno być postrzegane przez pryzmat pionów i wydziałów, lecz przez pryzmat realizowanych procesów i składających się na nie poszczególnych działań. Pierwszym etapem w projektowaniu rachunku kosztów działań jest właśnie wyodrębnienie działań oraz przypisanie im odpowiednich kosztów. Procesowy rachunek kosztów stanowi zatem podstawę dla szybkiego i sprawnego skonstruowania rachunku kosztów działań, gdyż skupia się on na wycenie kosztów działań będących elementami poszczególnych procesów w danej jednostce [Zieliński 2007, s. 37].

Procesowy rachunek kosztów dostarcza władzom zarządzającym jednostkami sektora finansów publicznych dodatkowych informacji niezbędnych do zidentyfikowania obszarów nieefektywności oraz potencjalnych usprawnień. Dzięki tym informacjom procesowy rachunek kosztów może mieć następujące 

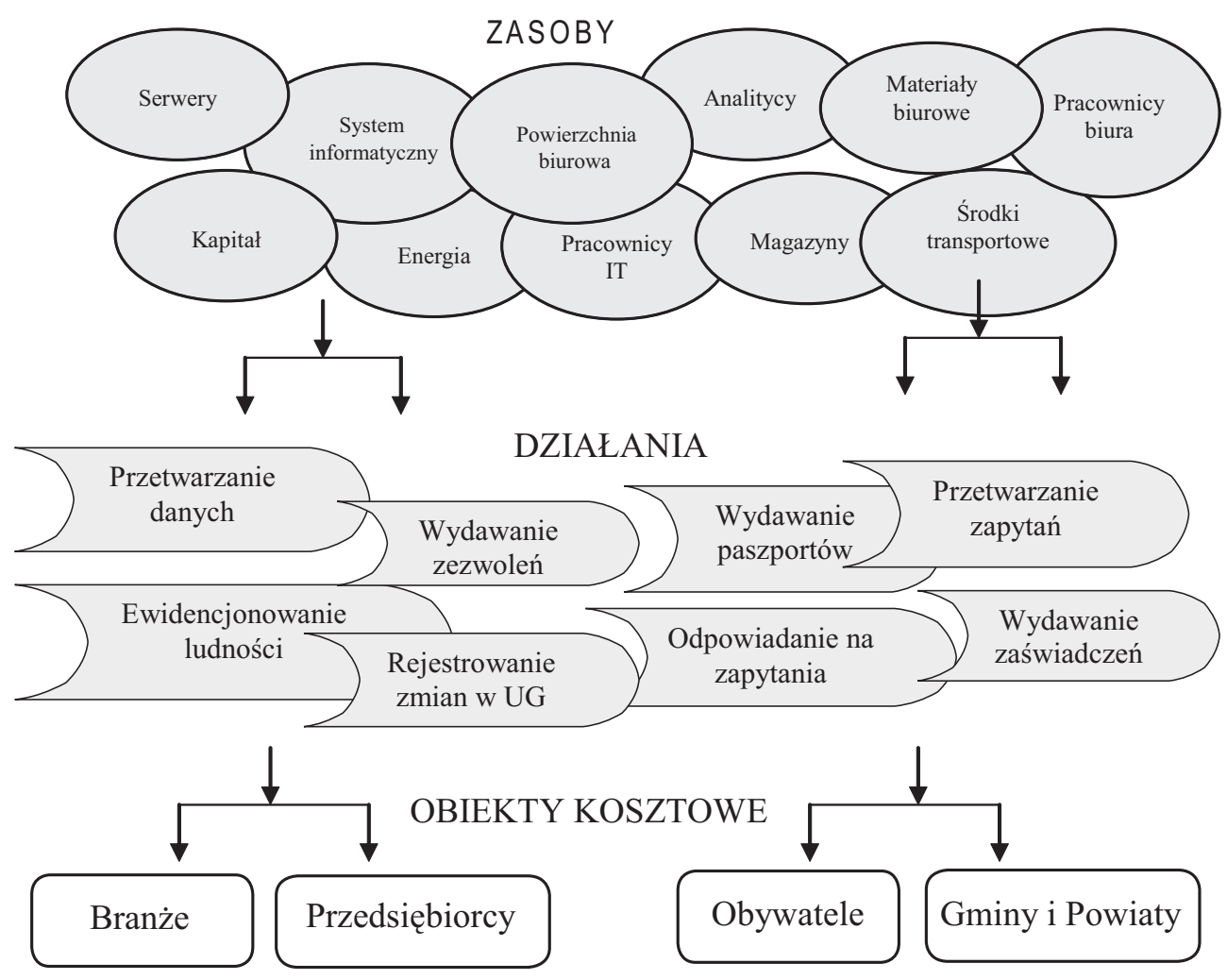

\section{Rysunek 1}

Struktura rachunku kosztów działań

Źródło: Skrypt Kancelarii Prezesa Rady Ministrów, Rachunkowość zarządcza a podejmowanie strategicznych decyzji w urzędzie administracji rządowej-część II, s. 27 (data dostępu: 21.05.2013).

zastosowanie i korzyści dla administracji publicznej [Skrypt Kancelarii Prezesa Rady Ministrów, s. 27]:

- zwiększenie efektywności świadczenia usług,

- uporządkowanie informacji o kosztach procesów oraz możliwość skutecznej kontroli i śledzenia kosztów w ujęciu kilkuset działań,

- monitorowanie efektywności procesów,

- dostęp do informacji wspierających zarządzanie procesami.

Innym czynnikiem sukcesu, a zarazem podstawą do wdrażania rachunku kosztów działań jest zasobowe postrzeganie kosztów. W tym przypadku jako drugi niezbędny element struktury systemu $\mathrm{ABC}$ są posiadane zasoby jednostki, które są wykorzystywane do wykonywania konkretnych działań. W początkowej fazie wprowadzenia koncepcji rachunku kosztów działań przez 
R. Kaplana i R. Coopera często pojawiały się problemy z prawidłowym rozliczeniem kosztów organizacji, co było wynikiem braku ewidencji kosztowej na poziomie zasobów. Problem dotyczył na przykład przypisania kosztu amortyzacji czy kosztu usługi obcej do działań. Z tego powodu powstał właśnie zasobowy rachunek kosztów, będący niejako dopełnieniem metody rachunku kosztów działań [Zieliński 2009, s. 7].

Istota zasobowego rachunku kosztów działań tkwi w przeorganizowaniu rachunku kosztów według miejsc powstawania kosztów. Kolejność postępowania jest następująca [Skrypt Kancelarii Prezesa Rady Ministrów, s. 28]:

- najpierw definiowane są pule zasobów (miejsca powstawania kosztów) reprezentujące poszczególne zasoby lub grupy jednorodnych zasobów (np. pracowników, usług obcych, urządzeń),

- po tak zdefiniowanych pulach zasobów księgowane są koszty rodzajowe związane $\mathrm{z}$ danym zasobem.

Zasobowe rachunki kosztów są więc bardziej rozbudowane niż te tradycyjnie konstruowane struktury miejsc powstawania kosztów. Przyczyną tego jest wielość zasobów organizacyjnych, jakimi dysponują instytucje. Brak tego rachunku już w pierwszej fazie wdrożenia rachunku kosztów działań uniemożliwia racjonalne rozliczanie kosztów na procesy [Zieliński 2009, s. 7].

Wśród podstawowych zalet zasobowego rachunku kosztów wyróżnić należy [Skrypt Kancelarii Prezesa Rady Ministrów, s. 27]:

- $\quad$ szanse na obniżenie kosztów dzięki ścisłej kontroli kosztów oraz potencjału na poziomie poszczególnych zasobów organizacyjnych,

- uzyskanie doskonałej podstawy do wdrożenia koncepcji rachunku kosztów działań (Activity BasedCosting) pozwalającej na przyczynowo-skutkową wycenę kosztu procesu obsługi poszczególnych klientów i świadczenia usług,

- przejrzystą ewidencję kosztów posiadanych zasobów umożliwiającą menedżerom sprawne zarządzanie poziomem i wykorzystaniem zasobów - przyjęcie zasobowego rachunku kosztów sprawia, ze każdy koszt musi być przypisany do konkretnego zasobu, stąd zmniejsza się liczebność i znaczenie tzw. worków kosztów, gdzie „wrzucane” są koszty bez głębszego zastanowienia i kontroli,

- Ścisłą kontrolę kosztów na poziomie posiadanych zasobów pozwalająca na kalkulowanie jednostkowych stawek przerobu zasobów, a przez to lepsze zarządzanie potencjałem i kosztami zasobów,

- lepszą możliwość dopasowywania poziomu zasobów do rozmiaru działalności - dzięki zrozumieniu dostępnego potencjału zasobów oraz zmierzeniu kosztów jego utrzymania menedżerowie efektywniej zarządzają zasobami i kosztami niewykorzystanych zasobów, 
- $\quad$ szerokie możliwości analityczne w zakresie analizy kosztów - z tytułu samej wielości miejsc powstawania kosztów reprezentujących poszczególne zasoby lub ich jednorodne grupy,

- lepsze budżetowanie kosztów dzięki zasobowemu ujęciu i zrozumieniu podstawowej natury kosztów posiadanych zasobów - budżetowanie kosztów na poziomie konkretnego zasobu (np. budynku, samochodu jest po prostu łatwiejsze niż budżetowanie kosztów dla całego działu). Organizacje, które dokładnie budżetują koszty i tak w kalkulacjach osiagają poziom poszczególnych zasobów,

- doskonałe wsparcie do podejmowania decyzji inwestycyjnych w zasoby organizacji - decyzje inwestycyjne związane z wymianą zasobów wymagaja informacji kosztowej na poziomie zasobów.

Aktualnie rekomendowane na świecie rachunki kosztów jak ABC postulują coraz bardziej precyzyjną kalkulację kosztów. Oznacza to, że przed organizacjami stoi ogromne wyzwanie w rozwoju kompetencji z obszaru rachunkowości zarządczej, które pozwolą rozwijać w przyszłości coraz bardziej zaawansowane i precyzyjne systemy zarządzania kosztami w administracji publicznej.

\section{Istota rachunku działań w publicznej uczelni wyższej}

W jednostkach sektora finansów publicznych, między innymi na uczelniach wyższych, do niedawna nie było konieczności stosowania narzędzi rachunkowości zarządczej. Ostatnie lata przynoszą jednak zmiany, które narzucają na poszczególne jednostki obowiązek prowadzenia precyzyjnej kalkulacji kosztów. Taki obowiązek wprowadzono również na wyższych uczelniach publicznych, w których ze względu na specyfikę ich działalności skutecznym rozwiązaniem może okazać się wdrożenie rachunku kosztów działań. Dlatego też obiektem badań stała się publiczna uczelnia wyższa.

Ze względu na brak danych do przeprowadzenia kalkulacji kosztów, w pracy skupiono się na opracowaniu uproszczonego modelu rachunku kosztów działań dla hipotetycznej publicznej uczelni wyższej oraz identyfikacji problemów związanych z wdrożeniem tego narzędzia do jej systemu rachunkowości. Wszelkie informacje dotyczące funkcjonowania opisywanej uczelni zostały zdobyte techniką wywiadu z pracownikami wybranych wyższych uczelni publicznych oraz na podstawie analizy statutów oraz materiałów udostępnianych na stronach internetowych uczelni publicznych.

Do misji wszystkich publicznych uczelni wyższych należy przede wszystkim kształcenie studentów na jak najwyższym poziomie zgodnie z potrzebami wynikającymi z rozwoju gospodarczego kraju. Oprócz kształcenia studentów 
ważnym zadaniem uczelni jest prowadzenie badań naukowych przyczyniających się do postępu cywilizacyjnego oraz poszerzania kwalifikacji kadr naukowych. Poprzez partnerską współpracę z różnego rodzaju instytucjami krajowymi lub zagranicznymi uczelnie wyższe tworzą podstawy do rozwoju regionalnego, wdrażając uzyskane wyniki badań naukowych do praktyki gospodarczej.

Funkcjonowanie wyższych uczelni publicznych w Polsce wiąże się z pełnieniem przez nie określonych w ustawach zadań. Specyfika tych zadań wpływa na tworzenie wewnętrznej struktury organizacyjnej. Analizując budowę oraz funkcje pełnione przez poszczególne komórki organizacyjne na kilku uczelniach można stwierdzić, iż możliwe jest stworzenie uniwersalnej struktury organizacyjnej dla większości uczelni wyższych. Struktura ta przedstawiona została na rysunku 2.

Struktura organizacyjna uczelni wyższej jest bardzo rozbudowana, zatem system zarządzania nią powinien być opracowany precyzyjnie, uwzględniając wszystkie komórki wchodzące w jej skład. Twierdzenie Matuszczaka oraz Juchy [www], że: „prowadzenie uczelni wyższych, niezależnie od wykonywanych przez nie funkcji społecznych, coraz bardziej upodabnia się do zarządzania przedsiębiorstwem" ma tutaj duże znaczenie. To zdanie idealnie odzwierciedla, jak skomplikowane jest zarządzanie tak złożoną jednostką jaką są uczelnie wyższe. Na szczególną uwagę zasługuje system finansowy prosperujący w publicznych uczelniach wyższych. Rozdysponowanie środków między poszczególne wydziały wymaga bowiem gruntownej analizy ich potrzeb. Należy jednak pamiętać, iż uczelnia wyższa to nie tylko wydziały, ale również (jak można zauważyć na rys. 2) szereg komórek zapewniających sprawne funkcjonowanie tej jednostki.

Podstawą podejmowania decyzji w procesie zarządzania całą uczelnią jest znajomość przychodów oraz kosztów powstających w trakcie funkcjonowania jednostki oraz poziomu kosztów wydatkowanych na jednego studenta.

Ze względu na wysoki stopień trudności wdrożenia rachunku kosztów działań w zakresie całej uczelni, w niniejszej pracy szczegółowej analizie zostanie poddany hipotetyczny wydział. Na podstawie specyfiki jego funkcjonowania utworzony zostanie uproszczony model rachunku kosztów działań. Aby przejść do szczegółowych analiz kosztów warto przyjrzeć się strukturze organizacyjnej, jaką posiada dany wydział. Jako przykład takiej struktury w niniejszej pracy posłużono się hipotetycznym Wydziałem Finansów (rys. 3).

Przedstawiona na rysunku 3 struktura organizacyjna może stanowić odzwierciedlenie funkcjonowania większości wydziałów na wyższych uczelniach publicznych. Na czele każdego wydziału stoi dziekan, który nadzoruje jego funkcjonowanie. Odpowiednio do poszczególnych obszarów działalności tworzone są komisje wydziałowe odpowiedzialne za rozwiązywanie problemów dotyczą- 


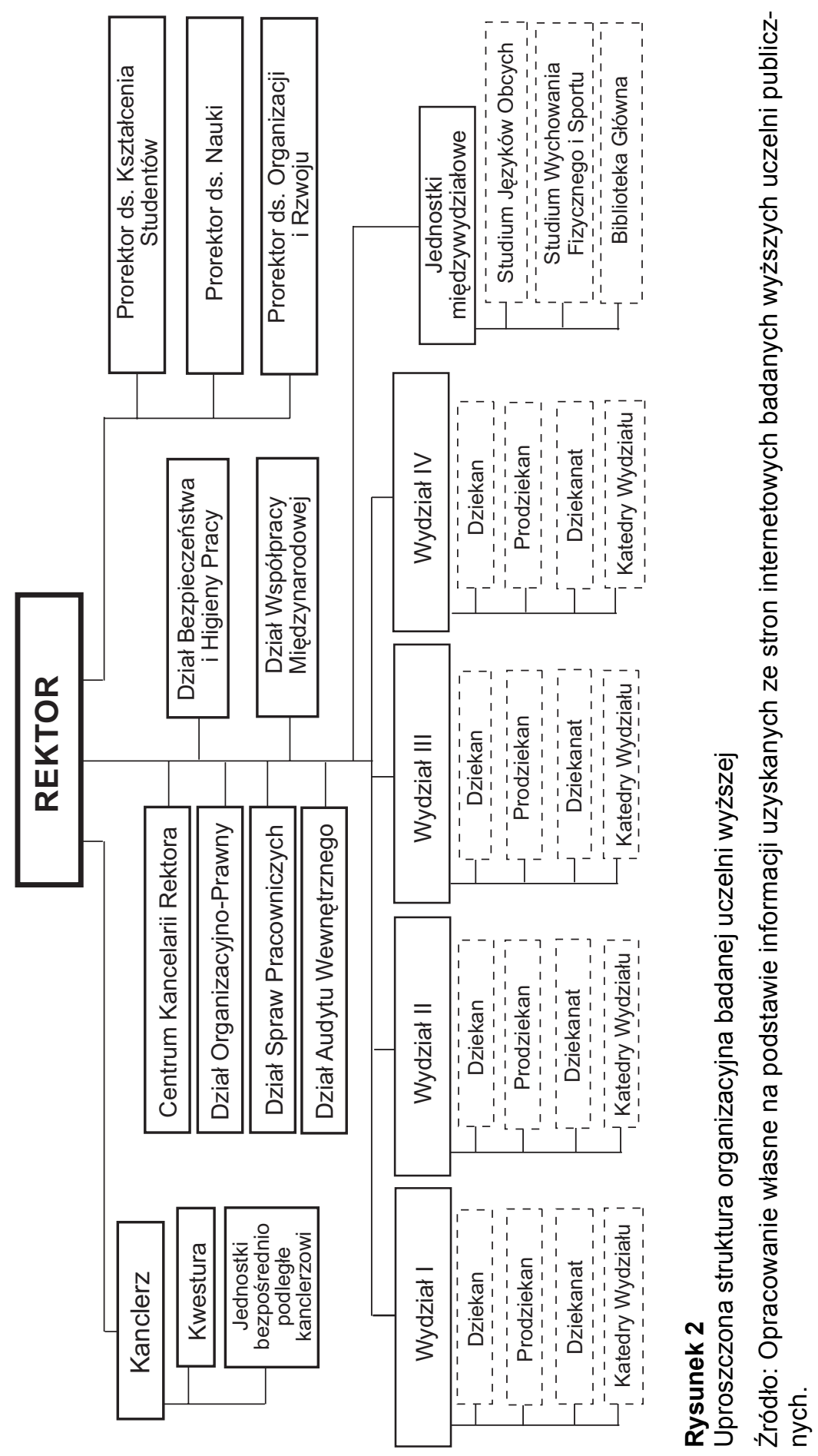




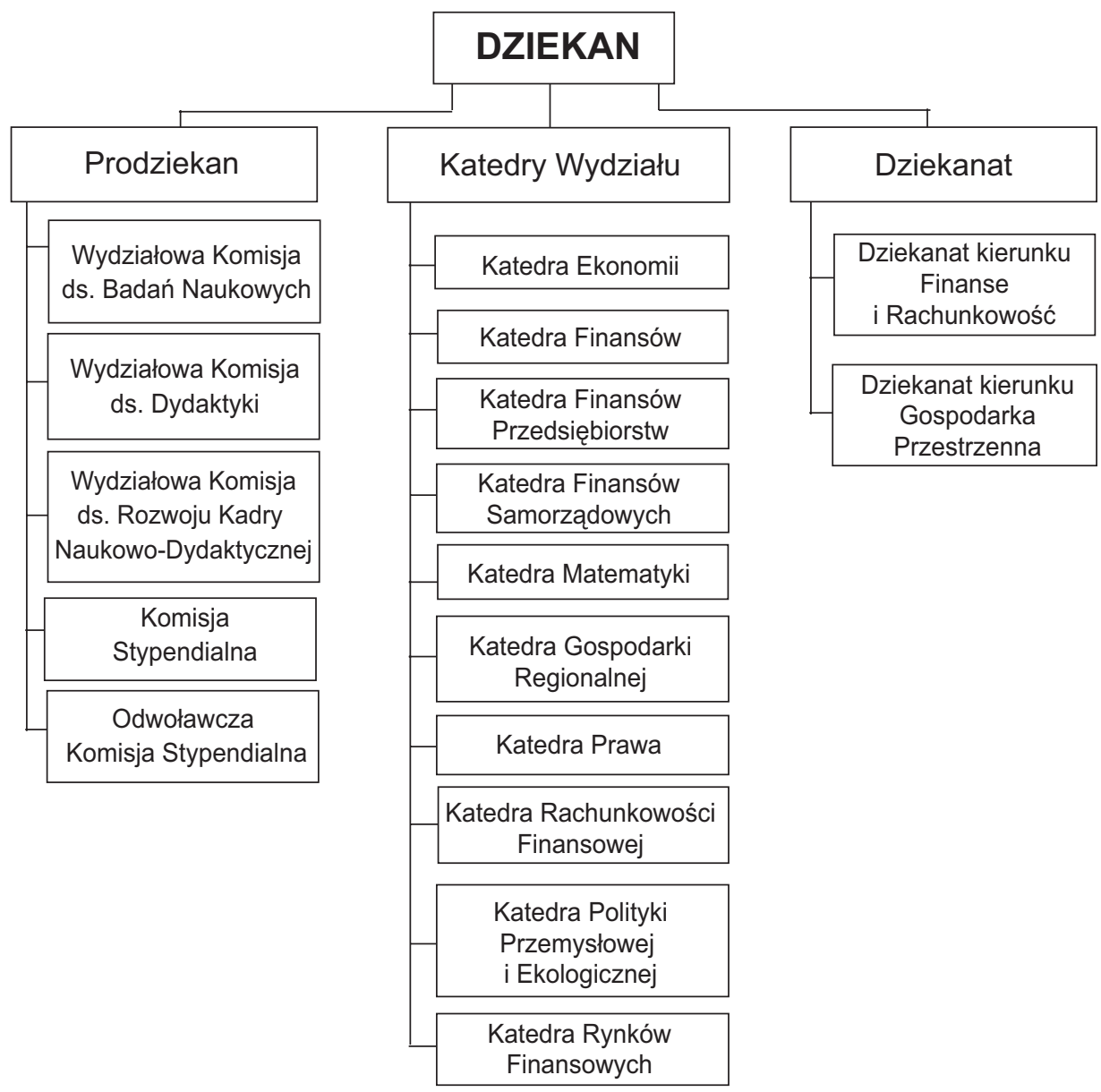

\section{Rysunek 3}

Struktura organizacyjna Wydziału Finansów

Źródło: Opracowanie własne na podstawie informacji zawartych na stornie internetowej jednego $z$ uniwersytetów ekonomicznych.

cych danego zakresu obowiązków. Poszczególne wydziały mogą się różnić liczbą kierunków, na jakich kształcą studentów oraz liczbą katedr, które dopasowane są odpowiednio do profilu kształcenia na konkretnym kierunku.

$\mathrm{Na}$ uczelniach wyższych studia prowadzone są zarówno w trybie stacjonarnym, jak również niestacjonarnym, co przyczynia się do podniesienia stopnia skomplikowania rozliczania kosztów. Ponadto jeden wykładowca może być powiązany z większą ilością kierunków, a nawet wydziałów na danej uczelni. Sytuacje takie utrudniają rozliczenie udziału jego wynagrodzenia w koszcie kształcenia jednego studenta. 
Uczelnia wyższa w związku z jej charakterystycznym modelem funkcjonowania stanowi dosyć interesujący przedmiot analizy związany z wdrożeniem rachunku kosztów działań. Do utworzenia uproszczonego modelu tej metody konieczne jest dogłębne poznanie zadań, jakie stawiane są przed uczelniami wyższymi oraz ich rozkład na procesy, tworzące je działania i potrzebne do ich wytworzenia zasoby.

\section{Zadania i funkcje wybranej jednostki}

Jak każda organizacja sektora finansów publicznych, państwowa uczelnia wyższa spełnia wiele ściśle określonych zadań oraz funkcji z nich wynikających. W związku z publicznym charakterem tych jednostek, zadania jakie spełniaja muszą odpowiadać normom prawnym, a także statutom ustanowionym przez władze uczelni.

Zadania jakie spełnia uczelnia wyższa podzielić można na dwie grupy, spośród których jedna wiąże się z działalnością dydaktyczną, druga zaś z działalnością badawczą. Szczegółowy schemat przedstawiający podział zadań pomiędzy te dwie kategorie przedstawia rysunek 4 .

Działalność dydaktyczna polega na kształceniu studentów na kierunkach zawartych $w$ ofercie uczelni. Oferta dotycząca kierunków kształcenia przyszłych kadr powinna być ściśle powiązana z zapotrzebowaniem jakie występuje na rynku, a także z popytem na specjalistów poszczególnych branż, jaki wystapi w przyszłości. Kształcenie to powinno odbywać się na jak najwyższym poziomie, dorównując standardom światowym.

Działalność badawcza i naukowa obejmuje szeroki obszar naukowo-badawczy. Efektem tej działalności są między innymi: współpraca z uczelniami zagranicznymi, udział w konferencjach i sympozjach krajowych oraz zagranicznych, a także liczne publikacje naukowe.

Oprócz podstawowych zadań uczelni wyższych ukazanych na rysunku 4, mogą one spełniać wiele innych powinności wynikających z profilu ich kształcenia. Przykładem może być jednostka kształcąca na kierunkach medycznych, która dodatkowo ma za zadanie wykonywanie świadczeń zdrowotnych w ramach kształcenia studentów. Kolejnym przykładem są uczelnie morskie, które poza zadaniami związanymi z działalnością dydaktyczną i badawczą zobowiązane są do utrzymywania statków szkolnych oraz specjalistycznych ośrodków szkoleniowych dla kadr morskich. Istnieją jednak zadania niepowiązane z dzielnością dydaktyczną i badawcza, ale swym zakresem obejmujące praktycznie wszystkie uczelnie - dotyczą one zapewnienia bezpiecznych i higienicznych warunków pracy i nauki studentom oraz pracownikom. Ponadto uczelnie prowadzą domy studenckie, a w ramach propagowania kultury mogą zajmować się utrzymaniem i administrowaniem klubów studenckich czy też ośrodków sportowych. 


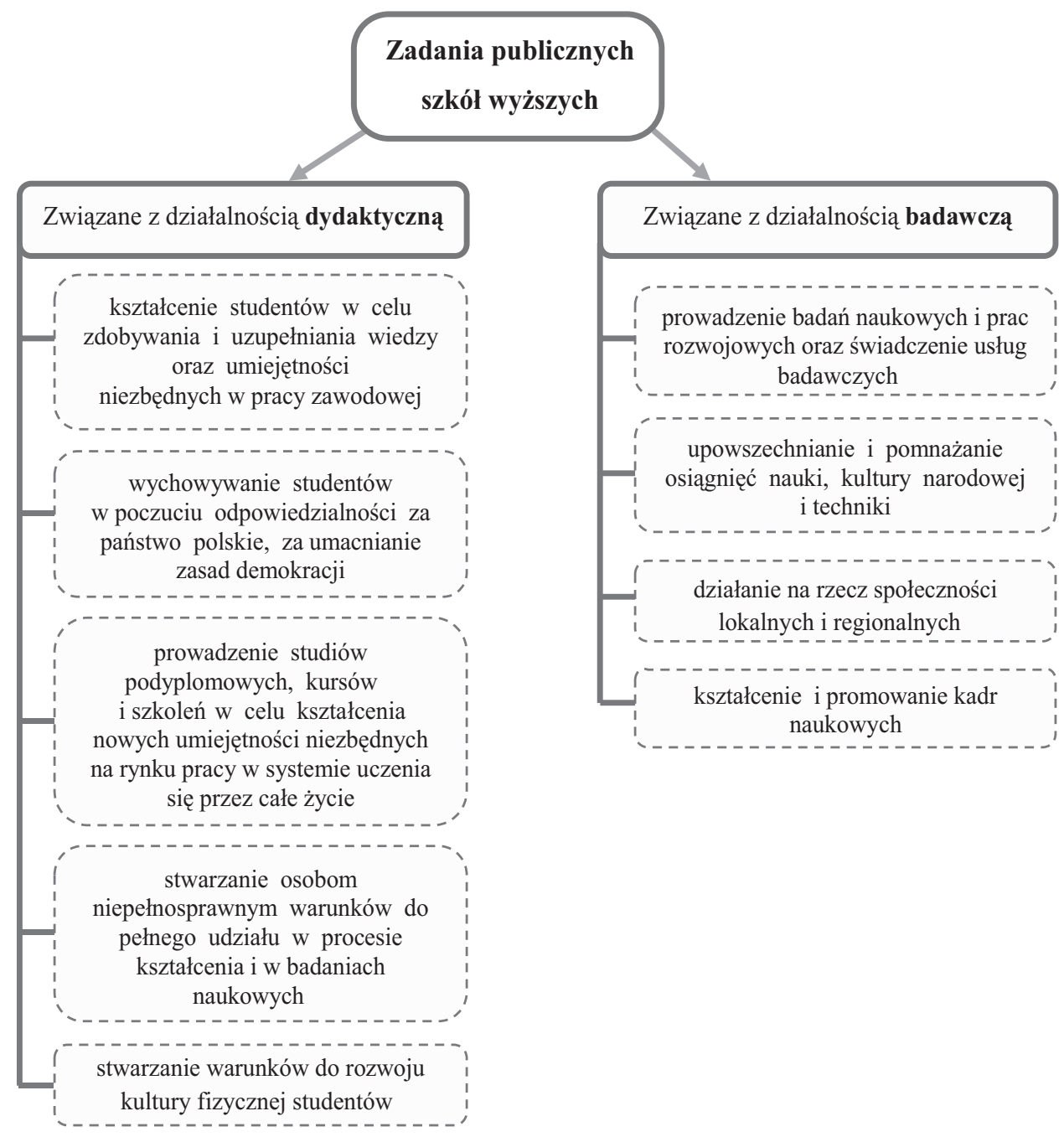

\section{Rysunek 4}

Zadania szkół wyższych publicznych

Źródło: Opracowanie własne na podstawie Ustawy z dnia 27 lipca 2005 r. Prawo o szkolnictwie wyższym, art. 13 (Dz.U. z 2005 r. nr 164, poz. 1365, z późn. zm.).

Zadania uczelni wyższej ściśle powiązane są z jej statutem, kierunkami kształcenia oraz specyfiką funkcjonowania. Realizowane przez daną uczelnie zadania stają się źródłem funkcji, które dzięki nim spełnia. Do podstawowych funkcji wyższej uczelni publicznej można zaliczyć:

- $\quad$ funkcje dydaktyczne - ma na celu profesjonalne przygotowanie studentów do pracy zawodowej w zakresie teoretycznym oraz praktycznym, 
- funkcje wychowawcze - związane z kształtowaniem poglądów oraz osobowości studentów, rozpowszechnianie wśród nich wartości moralnych,

- funkcje rozwojowe - rozwijanie zainteresowań poprzez ofertę kół naukowych, a także szansa samorozwoju dzięki działaniom w samorządach studenckich itd.

Na uczelni wyższej spoczywa zatem nie tylko obowiązek wypełnienia podstawowych zadań, ale przede wszystkim odpowiedzialność za efektywne wypełnienie swych funkcji, gdyż ten etap kształcenia jest ważnym stadium w życiu człowieka, kiedy to w pełni kształtuje się jego osobowość.

\section{Identyfikacja działań i procesów}

Ważnym etapem do zaprojektowania modelu kosztów działań dla hipotetycznego wydziału uczelni wyższej jest wyodrębnienie działań oraz procesów, jakie występują na tym wydziale.

Główne grupy kosztowe w uczelni stanowią te związane z podstawowym zakresem zadań, a więc koszty działalności dydaktycznej oraz koszty działalności badawczej. Zgodnie z analizą kosztów udostępnionych przez jedną z badanych w tej pracy uczelni, działalność dydaktyczna wytwarza aż 91\% ogółu wydatków tej uczelni, na działalność badawczą przeznacza się natomiast pozostałe 9\%.
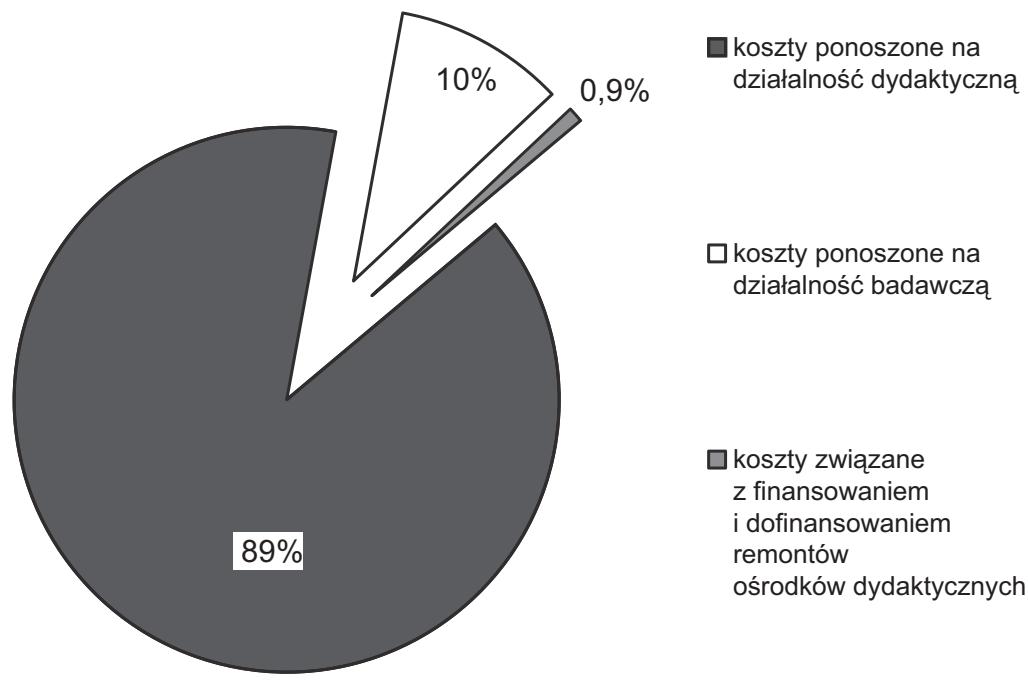

\section{Rysunek 5}

Struktura kosztów ponoszonych na działalność operacyjną na uczelni

Źródło: Opracowanie własne na podstawie Sprawozdania Rektora z działalności Uczelni w roku akademickim 2011/2012. 
Struktura rozkładu kosztów na pozostałych uczelniach jest podobna jak ta przedstawiona na rysunku 5. Nieznacznie mogą się zmieniać proporcje środków przeznaczanych na poszczególne działalności, co może być skutkiem zróżnicowanych potrzeb związanych z kształceniem na danych kierunkach. W związku z tym rozpiętość kosztu kształcenia na różnych kierunkach jest bardzo duża. $Z$ pewnością koszt ten będzie wyższy w przypadku studenta kierunków medycznych czy wojskowych, niższy zaś dla studentów ekonomii.

Wszystkie koszty, niezależnie od struktury ich rozkładu, należy podzielić w pierwszej kolejności na koszty bezpośrednie oraz koszty pośrednie, które następnie dzięki rachunkowi kosztów działań zostaną rozliczone za pomocą odpowiednich kluczy. Podczas wyodrębniania tych kosztów należy pamiętać, iż na badanym wydziale, oprócz kosztów związanych bezpośrednio z jego funkcjonowaniem, do obliczenia kosztu kształcenia jednego studenta wliczane są koszty związane z organizacją pracy całej uczelni, na przykład koszty administracyjne, koszty prowadzenia biblioteki czy też studenckich stołówek. Dla ułatwienia

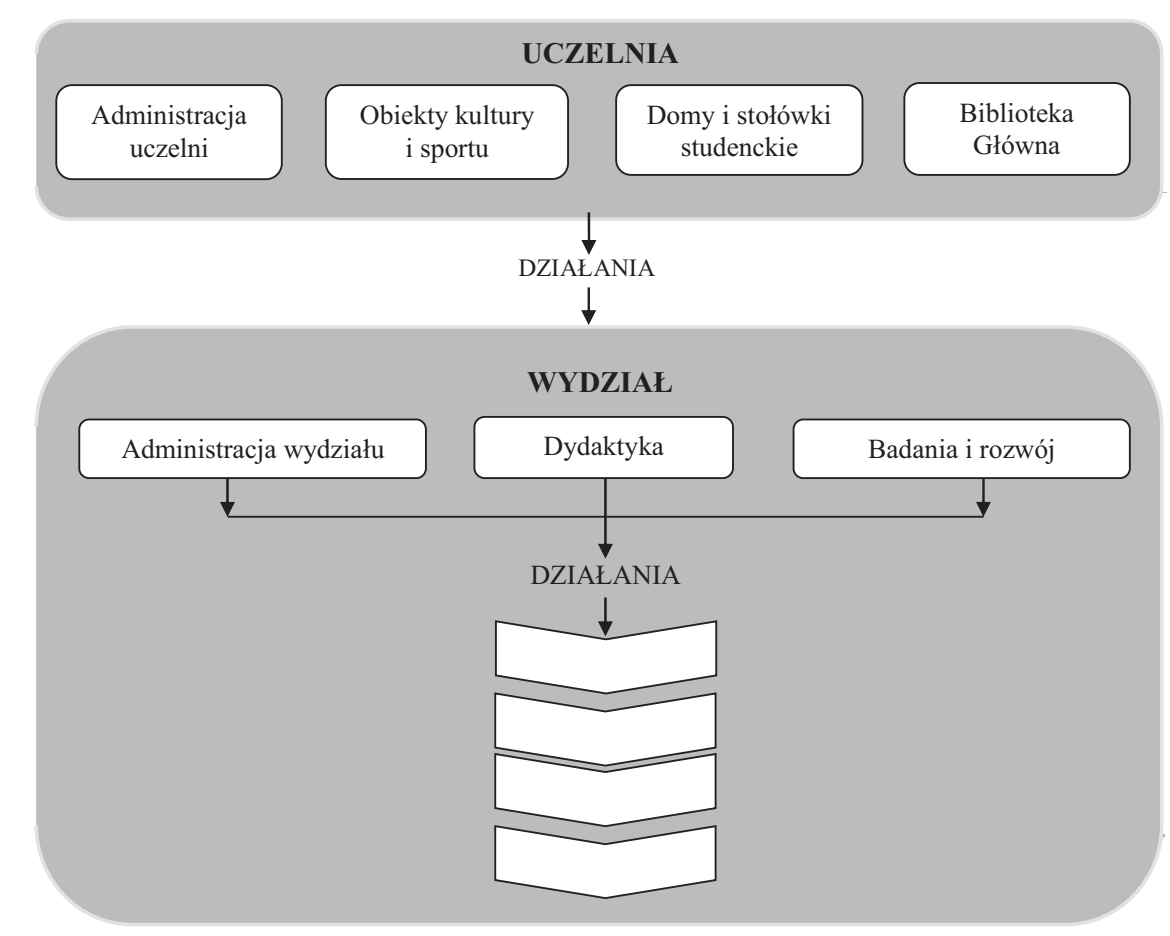

Rysunek 6

Uproszczony model rachunku kosztów działań

Źródło: Opracowanie własne. 
identyfikacji wszystkich działań składających się na proces kształcenia na rysunku 6 przedstawiono uproszczony model ABC dla potencjalnego wydziału uczelni wyższej z wydzielonymi obszarami powstawania tych działań.

Biorąc pod uwagę, że poszukiwany jest koszt kształcenia jednego studenta konkretnego kierunku uczelni wyższej, stwierdzić można, iż analogicznie do przedsiębiorstwa produkcyjnego, w tym przypadku produktem końcowym będzie właśnie jeden student. Według terminologii metody $\mathrm{ABC}$ student określony jest natomiast jako obiekt kosztowy.

W zakresie danego wydziału, na którym kształci się student, możemy wyróżnić poszczególne procesy, które składają się na cały etap edukacji. W ramach procesów możemy natomiast wyszczególnić wykonywane działania. Zgodnie z rysunkiem 6 , miejsca powstawania kosztów można podzielić na te związane $\mathrm{z}$ wydziałem, na kierunku którego kształci się dany student oraz koszty ogólne uczelni, które powinny być rozliczone na każdy wydział. Taki podział przyczynia się do wykonywania różnych działań odpowiednich do charakteru działalności poszczególnych komórek. W tabeli 1 ukazano procesy i działania wyodrębnione w zakresie całej uczelni, ze względu na ich dużą ilość zamieszczone zostały tylko te najważniejsze.

Tabela 1

Mapa procesów, działań i zasobów uczelni wyższej dotyczące jej ogólnych funkcji

\begin{tabular}{|c|c|c|}
\hline Procesy & Działania & Zasoby \\
\hline $\begin{array}{l}\text { Administracja uczelni } \\
\text { (rektor, prorektorzy, } \\
\text { działy uczelni, kwestu- } \\
\text { ra, pozostałe komórki) }\end{array}$ & $\begin{array}{l}\text { - Kierowanie działalnością uczelni } \\
\text { - Reprezentacja uczelni na zewnątrz } \\
\text { - Opracowanie strategii rozwoju } \\
\text { - Kształtowanie polityki kadrowej i płacowej } \\
\text { - Opracowanie programu kształcenia } \\
\text { - Opracowanie sprawozdań z funkcjonowa- } \\
\text { nia uczelni } \\
\text { - Nadzór nad finansami uczelni } \\
\text { - Monitoring jakości kształcenia } \\
\text { - Obsługa pracowników i studentów } \\
\text { - Archiwizacja dokumentacji }\end{array}$ & $\begin{array}{l}\text { - Pracownicy } \\
\text { - Srodki transportu } \\
\text { - Urządzenia biurowe } \\
\text { - Materiały biurowe } \\
\text { - Serwery } \\
\text { - Systemy informatyczne } \\
\text { - Obiekty biurowe } \\
\text { - Archiwum } \\
\text { - Energia }\end{array}$ \\
\hline Obiekty kultury i sportu & $\begin{array}{l}\text { - Administrowanie obiektami kultury i sportu } \\
\text { - Organizacja imprez okolicznościowych } \\
\text { (np. zawody sportowe) } \\
\text { - Obsługa techniczna obiektów }\end{array}$ & $\begin{array}{l}\text { - Pracownicy } \\
\text { - Obiekty sportowe } \\
\text { - Obiekty ośrodków kultury } \\
\text { - Maszyny i urządzenia } \\
\text { - Energia } \\
\end{array}$ \\
\hline $\begin{array}{l}\text { Domy studenckie, } \\
\text { stołówki studenckie }\end{array}$ & $\begin{array}{l}\text { - Administrowanie domami oraz stołówkami } \\
\text { studenckimi } \\
\text { - Zapewnienie czystości w obiektach }\end{array}$ & $\begin{array}{l}\text { - Domy i stołówki studenckie } \\
\text { - Pracownicy }\end{array}$ \\
\hline Biblioteka Główna & $\begin{array}{l}\text { - Administrowanie pracą biblioteki } \\
\text { - Wydawanie kart członkowskich } \\
\text { - Wypożyczanie zasobów biblioteki }\end{array}$ & $\begin{array}{l}\text { - } \text { Biblioteka } \\
\text { - Pracownicy } \\
\text { - Książki,czasopisma itd. }\end{array}$ \\
\hline
\end{tabular}

Źródło: Opracowanie własne. 
Tabela 1 zawiera tylko część działań, jakie realizowane są w ramach funkcjonowania uczelni. Wymienione w niej działania dotyczą wszystkich wydziałów, co oznacza, że koszty generowane podczas ich wykonywania powinny być rozdzielone na każdy wydział zgodnie z obliczonym nośnikiem kosztu działań. Oprócz procesów i działań w tabeli 1 dokonano identyfikacji zasobów potrzebnych do wykonywanych działań oraz zapewniających sprawne prosperowanie uczelni.

Gdy znany jest już podział kosztów ogólnych uczelni, następnym krokiem w tworzeniu modelu rachunku kosztów działań jest analiza kosztów wydziałowych, a więc również procesów i działań przyczyniających się do ich powstawania (tab. 2).

Tabela 2

Mapa procesów, działań i zasobów charakterystycznych dla wydziału

\begin{tabular}{|c|c|c|}
\hline Procesy & Działania & Zasoby \\
\hline \multicolumn{3}{|l|}{$\begin{array}{l}\text { Procesy } \\
\text { podstawowe }\end{array}$} \\
\hline Dydaktyka & $\begin{array}{l}\text { - Przeprowadzenie wykładu, ćwiczeń, projektu itd. } \\
\text { - Przeprowadzenie egzaminu dyplomowego } \\
\text { - Przeprowadzenie szkolenia BHP } \\
\text { - Konserwacja obiektów i urządzeń }\end{array}$ & $\begin{array}{l}\text { - Nauczyciele akademiccy } \\
\text { - Obiekty szkoleniowe } \\
\text { - Urządzenia: rzutniki, } \\
\text { komputery itd. } \\
\text { - Pomoce naukowe }\end{array}$ \\
\hline \multicolumn{3}{|l|}{$\begin{array}{l}\text { Procesy } \\
\text { pomocnicze }\end{array}$} \\
\hline $\begin{array}{l}\text { Administracja } \\
\text { wydziału } \\
\text { (dziekan, } \\
\text { dziekanat, } \\
\text { komisje } \\
\text { wydziałowe, } \\
\text { pozostałe } \\
\text { komórki) }\end{array}$ & $\begin{array}{l}\text { - Przyznawanie studentom świadczeń materialnych } \\
\text { - Wydawanie zarządzeń } \\
\text { - Reprezentacja wydziału na zewnatrz } \\
\text { - Rekrutowanie kandydatów } \\
\text { - Pobieranie opłat za studia } \\
\text { - Ewidencja opłat za studia } \\
\text { - Wydawanie legitymacji studenckiej, indeksu } \\
\text { - Archiwizacja dokumentacji studentów } \\
\text { - Obsługiwanie bieżących spraw studentów } \\
\text { - Nadzór nad jakością kształcenia na wydziale }\end{array}$ & $\begin{array}{l}\text { - Pracownicy } \\
\text { - Urzadzenia biurowe } \\
\text { - Materiały biurowe } \\
\text { - Obiekty biurowe } \\
\text { - System informatyczny } \\
\text { - Energia }\end{array}$ \\
\hline $\begin{array}{l}\text { Badania } \\
\text { i rozwój }\end{array}$ & $\begin{array}{l}\text { - Przeprowadzenie badań } \\
\text { - Kursy dla kadr naukowych, } \\
\text { - Współpraca ze społecznością lokalną } \\
\text { - Publikacja zeszytów naukowych }\end{array}$ & $\begin{array}{l}\text { - Pracownicy } \\
\text { - Urządzenia biurowe } \\
\text { - Pomoce naukowe } \\
\text { - Materiały biurowe } \\
\text { - Pomieszczenia biurowe }\end{array}$ \\
\hline
\end{tabular}

Źródło: Opracowanie własne. 
Podobnie jak w przypadku całej uczelni, również tutaj występuje ogromna ilość działań realizowanych w zakresie poszczególnych procesów. $Z$ tego względu w tabeli 2 dokonano podziału na procesy podstawowe - bezpośrednio powiązane z kształceniem studentów oraz pomocnicze, które są szczególnie ważne dla rachunku kosztów działań. Na koszty wynikające z procesów pomocniczych składają się przede wszystkim koszty badań naukowych i koszty administracyjne wydziału, które agregują liczną grupę działań. Do tej drugiej grupy zaliczana jest praca dziekana, dziekanatu czy też komisji wydziałowych, których pracę trudno rozdzielić między poszczególne kierunki istniejące na danym wydziale.

Specyfikacja działań i procesów umożliwia rozkład kosztów, które one generują za pomocą odpowiednich nośników kosztów. Identyfikacja tych nośników jest czynnością niezbędną podczas projektowania modelu rachunku kosztów działań dla uczelni wyższych. Pierwszą grupą jaką należy wyodrębnić są nośniki kosztów zasobów, ponieważ to one wyznaczają, ile poszczególnych zasobów potrzebne jest do wykonania danego działania. Zasoby, które wykorzystywane są w procesie kształcenia studentów w uczelniach wyższych, wymienione zostały w tabeli 3 .

\section{Tabela 3}

Mapa nośników kosztów zasobów dla uczelni wyższej

\begin{tabular}{|l|l|}
\hline Zasoby & \multicolumn{1}{|c|}{ Nośniki kosztów zasobów } \\
\hline Pracownicy & $\begin{array}{l}\text { - Liczba pracowników dziekanatu obsługujących dany kierunek } \\
\text { - Liczba nauczycieli akademickich na danym kierunku } \\
\text { - Liczba pracowników administracyjnych }\end{array}$ \\
\hline Środki transportu & - Liczba przejechanych kilometrów \\
\hline Urządzenia biurowe & $\begin{array}{l}\text { - Liczba wykorzystywanych urządzeń (komputerów, rzutników itd.) } \\
\text { - Czas pracy urządzeń }\end{array}$ \\
\hline Materiały biurowe & - Ilość zużytego papieru \\
\hline Systemy informatyczne & - Liczba wymian tonerów do drukarek \\
\hline Obiekty biurowe & - Liczba licencji \\
\hline Archiwum & - Powierzchnia wykorzystywanych obiektów biurowych $\left(\mathrm{m}^{2}\right)$ \\
\hline Energia & - Powierzchnia wykorzystywanego obiektu $\left(\mathrm{m}^{2}\right)$ \\
\hline Obiekty sportowe & - Czas archiwizacji dokumentów jednego studenta \\
\hline Biblioteka Główna & - Poẃć zużytych kwh \\
\hline Obiekty szkoleniowe & - Powierzchnia wykorzystywanych obiektów $\left(\mathrm{m}^{2}\right)$ \\
\hline
\end{tabular}

Źródło: Opracowanie własne. 
Kolejną grupą nośników są nośniki kosztów działań, które umożliwiają rozdzielenie ogólnych kosztów poszczególnych działań wydziału lub całej uczelni na badany obiekt kosztowy, a zatem na jednego studenta. Przykładowe nośniki kosztów działań, które można zastosować w uczelni wyższej zostały przedstawione w tabeli 4 . W niektórych przypadkach do poszczególnych działań zostało przypisanych kilka nośników, ponieważ wykorzystanie któregoś z nich może być uzależnione od rodzaju informacji, które są gromadzone przez uczelnie.

\section{Tabela 4}

Mapa nośników kosztów działań

\begin{tabular}{|c|c|}
\hline Działania & Nośniki kosztów działań \\
\hline \multicolumn{2}{|c|}{ Działania uczeni wyższej } \\
\hline Opracowanie programu kształcenia & - Liczba kierunków na uczelni \\
\hline Monitoring jakości kształcenia & - Czas kontroli \\
\hline Archiwizacja dokumentacji & - Ilość archiwizowanych dokumentów \\
\hline Organizacja imprez okolicznościowych & $\begin{array}{l}\text { - Ilość zorganizowanych imprez } \\
\text { - Czas trwania przygotowań }\end{array}$ \\
\hline Wypożyczanie zasobów biblioteki & $\begin{array}{l}\text { - llość wypożyczonych zasobów } \\
\text { - Czas obsługi jednego studenta }\end{array}$ \\
\hline \multicolumn{2}{|c|}{ Działania wydziału } \\
\hline Przeprowadzenie wykładów, ćwiczeń, projektów & $\begin{array}{l}\text { - llość wykładów, ćwiczeń na kierunku } \\
\text { - Liczba studentów - uczestników wykładu }\end{array}$ \\
\hline Przeprowadzenie szkolenia BHP & $\begin{array}{l}\text { - Czas trwania szkolenia } \\
\text { - Liczba osób prowadzących szkolenie } \\
\text { - Liczba uczestników szkolenia }\end{array}$ \\
\hline Konserwacja obiektów i urządzeń & $\begin{array}{l}\text { - Czas konserwacji } \\
\text { - Ilość urządzeń poddanych konserwacji }\end{array}$ \\
\hline Przyznawanie studentom świadczeń materialnych & $\begin{array}{l}\text { - llość złożonych wniosków } \\
\text { - Czas rozpatrzenia jednego wniosku }\end{array}$ \\
\hline Wydawanie zarządzeń & $\begin{array}{l}\text { - Ilość wydanych zarządzeń } \\
\text { - Czas opracowania jednego zarządzenia }\end{array}$ \\
\hline Rekrutowanie kandydatów & $\begin{array}{l}\text { - Ilość przyjętych wniosków } \\
\text { - Czas rozpatrzenia jednego wniosku }\end{array}$ \\
\hline Pobieranie opłat za studia & - Liczba wystawionych faktur, rachunków \\
\hline Wydawanie legitymacji studenckiej, indeksu & $\begin{array}{l}\text { - Ilość wydanych legitymacji, indeksów } \\
\text { - Czas wydania jednej legitymacji/indeksu }\end{array}$ \\
\hline Obsługiwanie bieżących spraw studentów & - Średni czas obsługi studenta \\
\hline Współpraca ze społecznością lokalną & - Ilość organizacji współpracujących z wydziałem \\
\hline Publikacja zeszytów naukowych & $\begin{array}{l}\text { - Ilość opracowanych zeszytów naukowych } \\
\text { - Czas opracowania zeszytu naukowego }\end{array}$ \\
\hline
\end{tabular}

Źródło: Opracowanie własne. 
Dobór odpowiedniego nośnika kosztów działań dla danego działania jest istotnym elementem metody ABC. Dlatego też jego wybór związany jest z dwoma czynnikami: kosztem jego pomiaru oraz łatwością pomiaru. W uczelniach wyższych szczegółowy pomiar chociażby czasu obsługi jednego studenta w dziekanacie nie jest wykonywany w praktyce. Wdrożenie rachunku kosztów działań wymaga więc przede wszystkim zaangażowania pracowników, którzy będą rzetelnie wykonywać pomiary wykonywanych przez nich czynności.

Reasumując, powyższe mapy (specyfikacje) stanowić mogą model zidentyfikowanych działań, procesów, zasobów i nośników kosztów zasobów oraz nośników kosztów działań w każdej hipotetycznej uczeni wyższej. Mapy mogą zostać wykorzystane jako wzorcowe podczas wdrażania rachunku kosztów działań w licznych uczelniach publicznych i niepublicznych.

\section{Identyfikacja problemów związanych z wdrożeniem rachunku kosztów działań}

Rachunek kosztów działań ze względu na swą strukturę wymaga od uczelni wyższych wdrożenia wielu elementów, dzięki którym możliwe będzie uzyskanie danych niezbędnych do kalkulacji kosztów. Uzyskanie tych danych związane jest z wieloma problemami, ale ich prawidłowe rozpoznanie gwarantuje szybkie wprowadzenie odpowiednich rozwiązań.

Koszt kształcenia jednego studenta nie jest taki sam na wszystkich uczelniach. Na jego poziom ma wpływ nie tylko kierunek, w jakim kształci się student, aczkolwiek jest to ważny wyznacznik. Koszty przypadające na edukację jednego studenta mogą się różnić, chociaż nieznacznie, nawet wśród studentów tego samego kierunku lecz innych uczelni. Przyczyną takiego stanu rzeczy mogą być na przykład różnice w programach kształcenia czy też w wysokości kosztów administracyjnych. Rozbieżność w kosztach związana jest również z ilością studentów w grupach na danym kierunku, liczbą godzin zajęć w procesie kształcenia, formą zajęć, wykorzystywanymi pomocami dydaktycznymi (np. specjalistyczne laboratoria) itp. Poszczególne czynniki wpływające na koszt kształcenia wiążą się z wykonywaniem działań oraz wykorzystywaniem zasobów. Ich zastosowanie wymaga jednak wybrania odpowiednich nośników kosztów oraz wprowadzenia specjalnych metod ich pomiaru.

Identyfikację problemów pojawiających się podczas wdrażania metody rachunku kosztów działań w wyższych uczelniach publicznych należy rozpocząć od przyczyny ich powstawania. Otóż trudności związane z implementacją tej metody do struktur organizacyjnych uczelni leżą u podstaw prawnych. Do niedawna bowiem brak było aktów prawnych wymuszających precyzyjną kalku- 


\section{6}

lację kosztów w tych jednostkach. Od 2009 roku normy prawne zaczęły ulegać licznym przeobrażeniom, które dały początek pojawieniu się w systemach rachunkowości uczelni wyższych elementów rachunkowości zarządczej. Zmiany te rozpoczęły się stosunkowo niedawno, w związku z tym większość uczelni wyższych jeszcze nie zaczęła stosować odpowiednich narzędzi umożliwiających kalkulację kosztów. Brak szczegółowych instrukcji dotyczących wdrażania tych narzędzi przyczynia się jednak do generowania kolejnych problemów.

Następnym utrudnieniem jakie napotykają badane uczelnie wyższe podczas wprowadzania metody $\mathrm{ABC}$ jest fakt, iż oprócz prowadzonej rachunkowości finansowej nie posiadają one zaawansowanych narzędzi do rozliczania kosztów. W związku z tym ograniczona jest ich wiedza o kosztach, posiadane przez nie systemy rachunkowości nie są natomiast $\mathrm{w}$ stanie wygenerować istotnych informacji o miejscach powstawania kosztów czy też o poszczególnych kosztach składających się na cały proces kształcenia studenta. W związku z tym wymagane jest przeprowadzenie odpowiedniej rekonstrukcji systemu rachunkowości oraz zastosowanie sprawdzonych w przedsiębiorstwach komercyjnych narzędzi rachunkowości zarządczej.

Do wdrożenia w praktyce rachunku kosztów działań potrzebna jest jeszcze wykwalifikowana oraz zaangażowana kadra pracowników. Niestety tych dwóch czynników również bardzo często brakuje na badanych uczelniach wyższych. Nie istnieją bowiem komórki zatrudniające specjalistów, którzy byliby odpowiedzialni za identyfikację procesów oraz działań występujących w uczelni, a także za cały system kalkulacji kosztów. Do sprawnego funkcjonowania modelu ABC niezbędne jest również zaangażowanie pracowników administracji uczelni oraz poszczególnych wydziałów, ponieważ to oni mają możliwość ewidencji wszelkich danych potrzebnych do oszacowania jednostkowego kosztu kształcenia studenta danego kierunku. Pracownicy administracyjni, na przykład dziekanatu, ze względu na nadmiar obowiązków oraz braku odpowiednich szkoleń na temat katalogowania informacji potrzebnych do rachunku kosztów działań nie wykazują chęci do wykonywania dodatkowych zadań.

Kolejnym istotnym czynnikiem związanym z pojawieniem się komplikacji podczas wdrażania $\mathrm{ABC}$ dla uczelni wyższej jest bardzo duża liczba działań występujących w tej jednostce. Szczególnie trudne okazuje się oszacowanie kosztu kształcenia jednego studenta danego kierunku, ponieważ w proces jego edukacji często zaangażowanych jest wiele komórek organizacyjnych. Rozliczenie kosztów generowanych przez poszczególne komórki przypadające właśnie na tego studenta jest czynnością bardzo trudną. Najbardziej pracochłonne jest rozpoznanie wszystkich działań wykonywanych na konkretnym wydziale. W samym dziekanacie można wyróżnić kilkanaście działań wykonywanych na rzecz studentów, które powinny być rozliczone na jednego studenta za pomocą odpowiadających im 
kluczy rozliczeniowych. Poza licznymi działaniami zidentyfikowanymi w dziekanacie wyróżnić można jeszcze wiele innych powiązanych z danym wydziałem, np. dotyczące kosztów organizacyjnych, dydaktycznych, badawczych. Ta ogromna ilość działań wymaga wyodrębnienia z całej grupy tych najważniejszych, które najlepiej będą przedstawiać rozkład poszczególnych kosztów.

Kiedy wszystkie potrzebne działania zostanąjuż wyodrębnione, może się zdarzyć, że uczelnia nie będzie w stanie ich wykorzystać. Taka sytuacja ma miejsce ze względu na brak prowadzenia przez poszczególne jednostki odpowiedniej dokumentacji. Zazwyczaj jej prowadzenie nie jest wymagane przez władze uczelni.

Czasami, mimo dobrych chęci, zebranie niezbędnych danych może okazać się praktycznie niewykonalne. Przykładem może być obliczenie czasu pracy naukowców podczas prac badawczych. Istnieją także sytuacje, gdy jeden nauczyciel akademicki prowadzi zajęcia na kilku wydziałach. Rozliczenie kosztu jego pracy odpowiednio do poszczególnych kierunków czy też studentów wymaga zatem koordynacji pracy kilku wydziałów.

\section{Wnioski}

Problemy związane z uzyskaniem niezbędnych danych kosztowych do modelu $\mathrm{ABC}$ mogą być rozwiązywane przez uśrednianie tych najtrudniej dostępnych. Niestety efektem takiego postępowania będzie uzyskanie wyników obarczonych błędami. W związku z tym można przypuszczać, iż decyzje podejmowane przez władze uczelni, sugerujące się takimi niepewnymi informacjami, nie będą w pełni racjonalne.

Należy także podkreślić, że wprowadzony rachunek kosztów działań powinien być stale monitorowany pod względem aktualności danych, jak również działań składających się na proces kształcenia. Aby stosowany model ABC był wiarygodnym źródłem informacji dla władz uczelni, należy stosować go systematycznie. Oznacza to, że zarówno władze uczelni, jak i jej pracownicy powinni diametralnie zmienić swe podejście do ewidencjonowania wszelkich wykonywanych przez nich działań tak, aby uzyskane dane były stale dostępne i aktualne.

Czynników wpływających na różnego rodzaje komplikacje pojawiające się podczas wdrażania rachunku kosztów działań w uczelniach wyższych jest wiele. Główną ich przyczyną jest brak przepisów ujednolicających sposób rozliczania kosztów przez nie generowanych. Ze względu na brak takich norm należy szukać innych źródeł radzenia sobie z tymi problemami. Korzystnym zjawiskiem mógłby się okazać na przykład cykl szkoleń dla pracowników działów księgowości o metodach implikacji do systemów rachunkowości uczelni wyższych nowego narzędzia służącego analizie kosztów, czyli rachunku kosztów działań. 
Równie dobrym rozwiązaniem, proponowanym w niniejszym artykule, będzie również opracowanie na poziomie ustawowym w formie powszechnego wzoru mapy (specyfikacji) działań, procesów, zasobów i nośników kosztów zasobów oraz nośników kosztów działań możliwych do wykorzystania w każdej hipotetycznej uczeni wyższej. Dodatkowo opracowanie dokumentacji operacyjnej identyfikacji działań, procesów, zasobów i nośników oraz kalkulacji kosztu edukacji jednego studenta. Wzór ten miałby podobny charakter jak wzorcowy zakładowy plan kont, będący częścią systemu księgowego, który ma obowiązek posiadać i stosować każda osoba prawna oraz inne podmioty gospodarcze. Został podany jako obowiązkowy w swoim zarysie, ale z możliwością samodzielnego uszczegóławiania i modyfikacji stosownie do specyfiki działania podmiotu.

\section{Literatura}

GLYNN J., PERRIN J., MURPHY M.P., 2003: Rachunkowość dla menedżerów, Wydawnictwo Naukowe PWN, Warszawa.

KLAUS, RYŃCA R., KOWALSKI M., 2007: Analiza kosztów dziekanatu w szkole wyższej z wykorzystaniem rachunku kosztów działań, [w:] Badania Operacyjne i Decyzje 1.

MIŁOSZ H.: Jak ewidencjonować koszty studiów [w:] Forum Akademickie, FA 06/2012, http://forumakademickie.pl/fa/2012/06/jak-ewidencjonowac-koszty-studiow/ (data dostępu: 05.06.2013).

ZIELIŃSKI T., 2007: „As easy As ABC” Rachunek kosztów działań prosty jak abecadło, [w:] Controlling 5, (data dostępu: 28.05.2013), http://www.abcakademia.com.pl/cz1_ As\%20Easy\%20As\%20ABC.pdf.

Ustawa z dnia 27 sierpnia 2009 r. o finansach publicznych, art. 68 ust. 1 (Dz.U. z 2009 r. nr 157, poz. 1240).

Ustawa z dnia 27 sierpnia 2009 r. o finansach publicznych, art. 68 ust. 2 (Dz.U. z 2009 r. nr 157, poz. 1240).

Skrypt Kancelarii Prezesa Rady Ministrów, Rachunkowość zarzqdcza a podejmowanie strategicznych decyzji w urzędzie administracji rzqdowej - część II, (data dostępu: 21.05.2013).

Ustawa z dnia 27 lipca 2005 r. Prawo o szkolnictwie wyższym, art. 92, ust. 1 (Dz.U. z 2005 r. nr 164, poz. 1365 , z późn. zm.).

Ustawa z dnia 27 lipca 2005 r. Prawo o szkolnictwie wyższym, art. 99, ust. 2 (Dz.U. z 2005 r. nr 164, poz. 1365 , z późn. zm.).

\section{Abstrakt}

W związku z pojawieniem się kontroli zarządczej w sektorze finansów publicznych zastosowanie elementów rachunkowości zarządczej staje się rzeczą konieczną. Szczególnie wykorzystanie rachunku kosztów działań umożliwia reali- 
zację celów i zadań w sposób zgodny z prawem, efektywny, oszczędny i terminowy. Uczelnie wyższe jako jednostki sektora finansów publicznych zmuszone zostały do wprowadzenia założeń rachunku kosztów działań i w konsekwencji zidentyfikowania: zadań i działań statutowych i cząstkowych, nośników działań i nośników zasobów. Mimo przygotowania teoretycznego, wdrożenie rachunku rodzi problemy techniczne i organizacyjne w uczelniach, a dane uzyskane w poszczególnych uczelniach nie przystają do siebie (są nieporównywalne).

Słowa kluczowe: rachunek kosztów działań, kalkulacja kosztów, sektor publiczny

\section{Concept of a model ,,activity based costing in higher education institutions"}

\section{Abstract}

As a result of introducing internal control of the public finances, it is necessary to introduce the elements of management accounting in public entities. In particular, the use of activity based costing enables the realization of goals and objectives in a manner consistent with the law, effective, efficient and on time. Higher education institutions as public sector entities were obliged to introduce activity based costing assumptions and in consequences to identify statutory and partial tasks and activities, media activities and media resources. Despite theoretical preparation, implementation of management accounting raises technical and organizational problems in the universities. Moreover, the data obtained in individual institutions are not comparable.

Key words: activity based, costing, calculation of cost, public sector 
